\title{
Comparison of the Effectiveness of 8-Week Ultimate-fit Combined Field exercise and Tele-Exercise Program on Static and Dynamic Balance Parameters of the Elderly Man
}

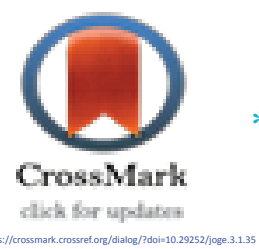

\section{*Babaei Khorzoghi $\mathrm{M}^{1}$, Sahebozamani $\mathrm{M}^{2}$, Karimi $\mathrm{MT}^{3}$}

1- Assistant Professor, Center of Physical Education, Isfahan University of Technology, Isfahan, Iran (Correspondent Author) E-mail: babaei@cc.iut.ac.ir \& mojtabasports@yahoo.com

2- Professor, Department of Sport Injury and Corrective Exercises, Faculty of Sport Sciences, Shahid Bahonar University, Kerman, Iran.

3- Rehabilitation Sciences Research Center, Shiraz University of Medical Sciences, Shiraz, Iran.

\section{Abstract}

Introduction: Falling is considered one of the most common problems of aging. Researchers believe that reducing the balance is - the main factor in falling the elderly. In this regard, the present study aims to comparison of the effectiveness of 8-week UF combined field training and tele-exercise program on static and dynamic equilibrium parameters of the ederly Man.

Method: This semi-experimental study was conducted in Isfahan, sixty healthy elderly men, aged 60-70 years old, had the ability to perform exercise activities, were selected through purposeful sampling and randomly divided into two experimental (field and tele-exercise) and control groups. Both experimental groups received intervention, exercise program sessions for 8 weeks, 3 sessions per week, and 90 minutes each session. A training program based on the UF training system was designed and implemented. Parameters related to static and dynamic balance were evaluated through a motion analysis device with seven cameras. For initial evaluations, a researcher-made questionnaire and a Mini Mental State Examination (MMSE) were used. Descriptive statistics were used for data analysis and their homogeneity and ANOVA for repeated measurements were used to analyze the data. SPSS version 24 was also used to perform statistical processes.

Results: The results showed that all three experimental and field experiments (tele-exercise) and control with age (P $=0.26)$, height $(\mathrm{P}=0.08)$, body weight $(\mathrm{P}=0 / 92)$, body weight index $(\mathrm{P}=0.95)$, fitness fitness index $(\mathrm{P}=0 / 43)$, mental health index $(\mathrm{P}=0 / 54)$, and general health $(\mathrm{P}=0 / 63=0)$ are homologous. The use of a combination exercise program as a tele- exercise and field exercise significantly increased some of the static balance parameters such as COP Excursion AP $(P=0 / 023)$ and ML $(P=0 / 019)$, Path Length AP $(P=0 / 001)$ and ML $(P=0 / 001)$, COP Velocity AP $(P=0 / 001)$ and ML $(\mathrm{P}=0 / 001)$ have a significant difference $(\mathrm{P}<0.05)$, This case was also obtained in the internal-external stability of the step width, which is one of the dynamic balance parameters $(\mathrm{P}<0.05)$. However, in the same period, in the group that did not practice the exercise program, there was no significant change in any of the parameters of static and dynamic balance $(\mathrm{P}>0.05)$.

Conclusion: Regarding the findings of the research, It can be deduced that regular and continuous use of a 8-week combined exercise program such as Tele-exercise and field exercise can be considered as a good alternative to field training programs due to the improvement of static and dynamic balance parameters.. Meanwhile, Tele-exercises seem to be more effective for the elderly age group because of the reduction of dangers outside the home and placement in matched groups, and pave the way for healthy aging and healthy living in this period of life.

Keyword's: Postural Balance, Tele-rehabilitation, Successful Elderly, Exercise Therapy.

Received: 10 June 2018

Accepted: 7 October 2018

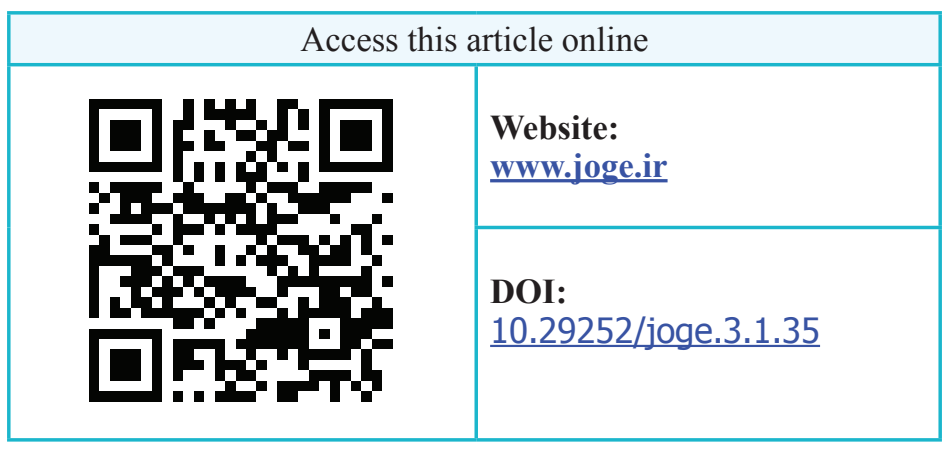




\title{
مقايسه اثربخشى ^ه هفته بر نامه تمرينى تركيبى "نهايت آمادكى" بصورت ميدانى و ورزش از راه دور بر روى بار امتر هاى تعادل ايستا و بوياى سالمندان مرد
}

\author{
"مجتبى بابيى خرزوقى'، منصور صاحب الزمانى '، محمدتقى كريمى" \\ (- استاديار، مركز تربيت بدنى، دانشكاه صنعتى اصفهان، اصفهان، ايران (نويسنده مسئول)

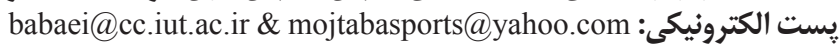

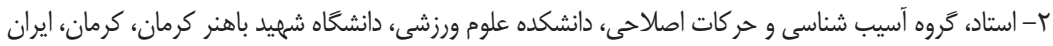

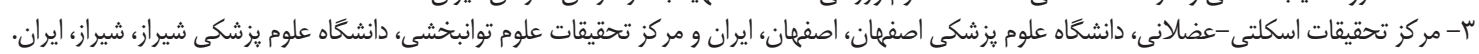

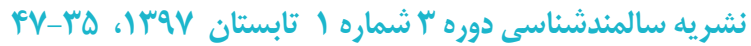

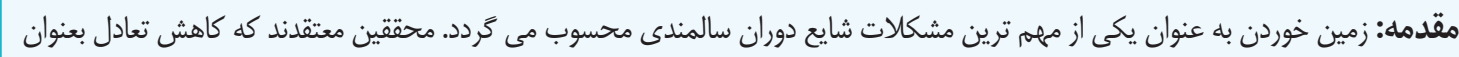

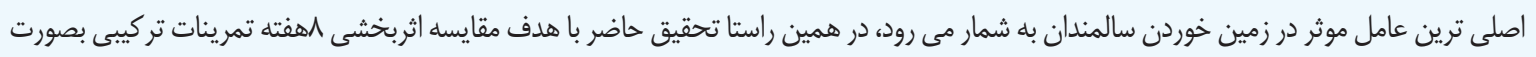

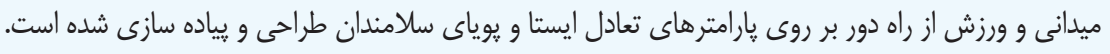

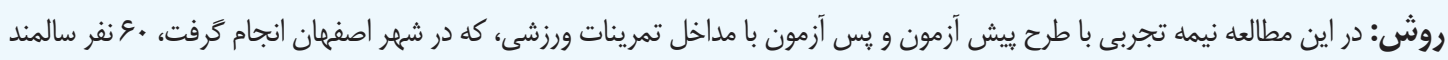

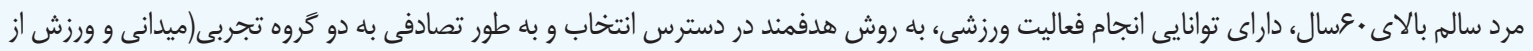

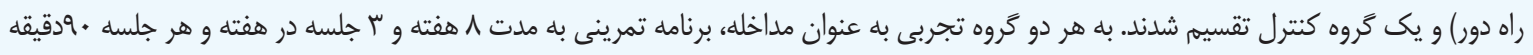

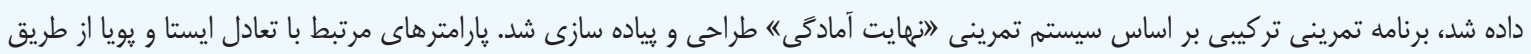

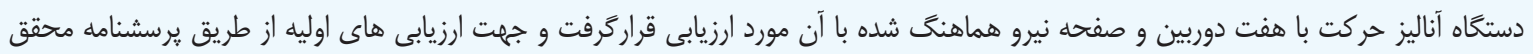

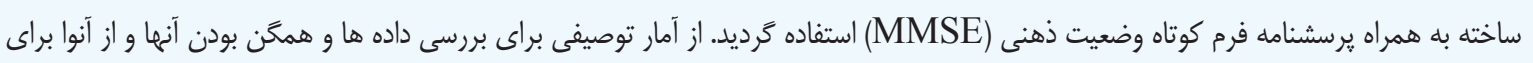

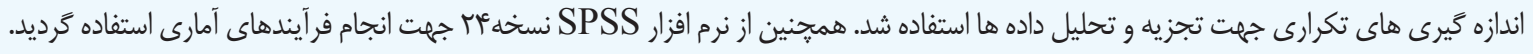

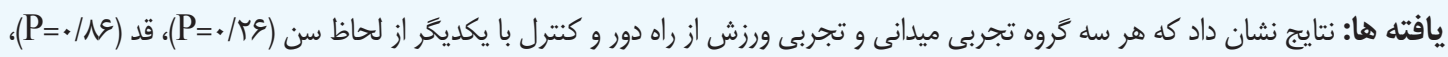

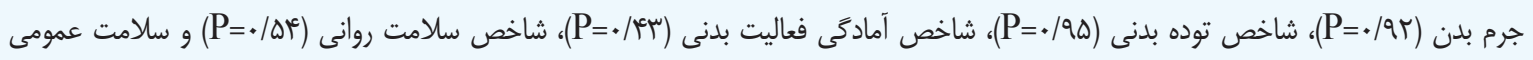

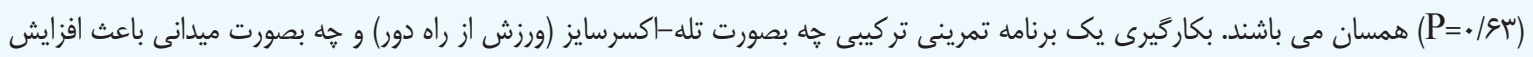

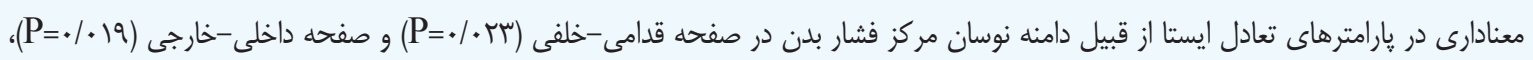

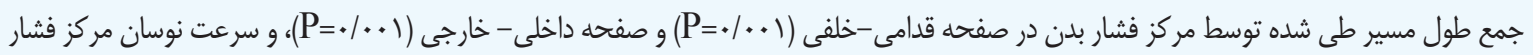

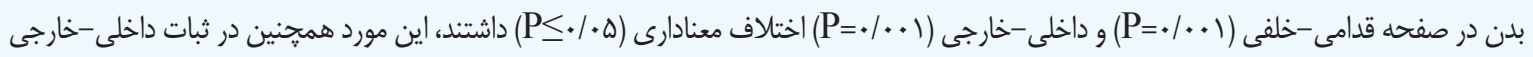

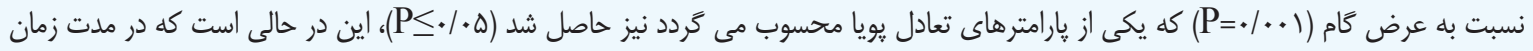

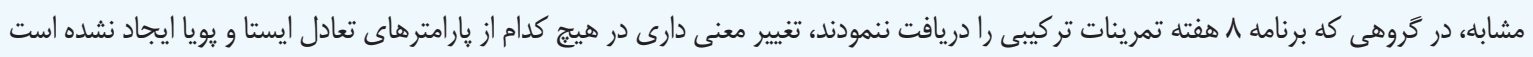

(P $\mathbf{P} \cdot / \cdot \Delta)$

نتيجه كَيرى: با توجه به يافته هاى حاصل از يُووهش، مى توان استنباط نمود كه استفاده منظم و مداوم از 1 هفتته برنامه تمرينى تركيبى بصورت

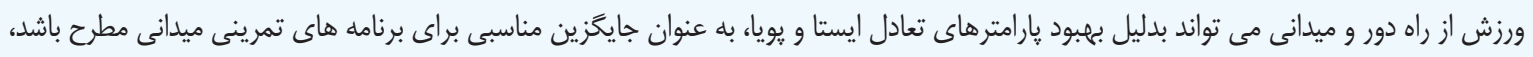

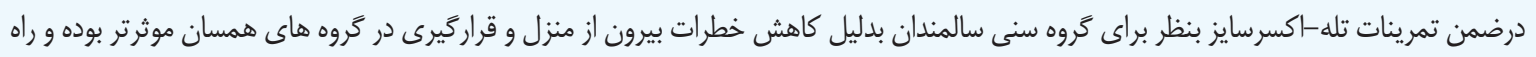

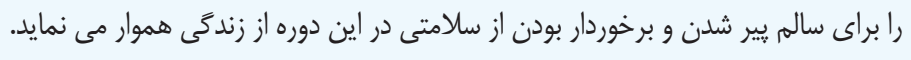

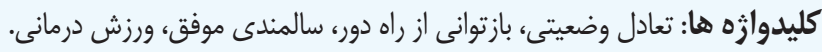


بدنى در دوران جوانى مى تواند به استقامت دوران سالمندى كمى

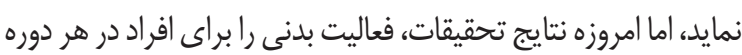
سنى مفيد نشان داده است (4(1). در نتيجه يكى از مواردى كه شايد توانسته باشد به طور اساسى بر روى سلامتى و تندرستى سالمندان نقش داشته باشد فعاليت بدنى منظمه و مداوم است (9)،هام). در همين راستا سازمان بهداشت جهانى عنوان مى دارد كه فعاليت بدنى منظهم،

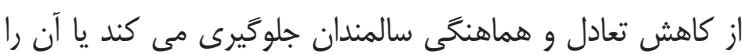
به تعويق مى اندازد. هدف از به كارگيرى فعاليت بدنى در سالمندان مقابله با ضعف، آسيب يذيرى ناشى از عدم فعاليت ورزشى، تغييرات بيولوزيك ناشى از سالمندى، بيماريهاى مزمن، سلامت روانى

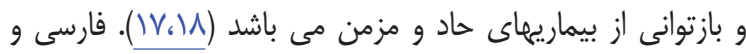

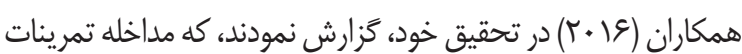
تعادلى مى تواند رويكرد موثرى در بهبود فاكتورهاى خطرزا در افتادن و توسعه جابجايى ايمن در جمعيت افراد سالمند باشد (19). در تحقيق ديخًرى نشان داده شد كه تمرينات يِيلاتس و قدرتى مى تواند باعث

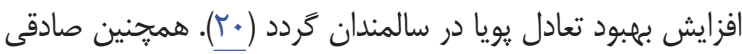

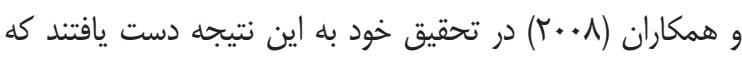
انجام تمرينات عملكردى در بهبود تعادل ايستاو يوياى مردان سالمند موثر است (Y). تمرينات تركيبى بر روى انواع پارامترهاى مرتبط به سلامت جسمانى موثر مى باشد. در همين راستا زارعى و همكاران

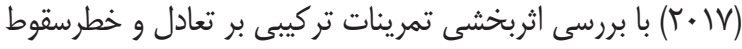
در سالمندان به اين نتيجه دست يافتند كه تمرينات تركيبى مى تواند

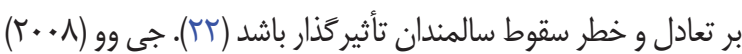
در تحقيق خود به بررسى تمرين از راه دور جهت ارتقاءو بهببود تعادل در سالمندان يرداخته و پֶ از ڤانزده هفته تمرين بهبود تعادل و كاهش خطر افتادن در سالمندان را بيان داشتند (سٓ). در همين راستا محققين به اين نتيجه دست يافته اند كه تمرينات از راه دور مى تواند تا حدى خطر افتادن در سالمندان را با بهبود سيستم تعادلى كاهش دهد (هآ، (Y). علاوه بر آن مى توان به اثربخشى تمرينات مبتنى بر فضاى سايبرى(ورزش از راه دور يا تله-اكسرسايز) بر روى كمردرد، كردن درد و ساير اختلالات اسكلتى-عضلانى اشاره نمود، كه به

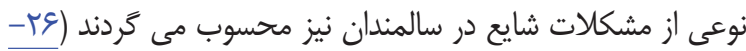

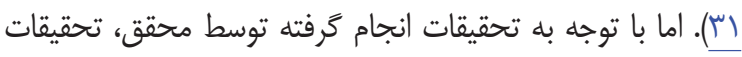
ناكافى در بررسى تمرينات از راه دور بر روى بارامترهاى تعادل ايستا

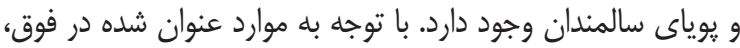
هدف از انجام مطالعه حاضر مقايسه اثربخشى 1 هفته برنامه تمرينى

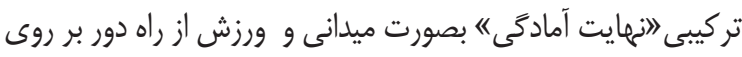

dode

يكى از دوران حساس زندگى بشر، دوران سالمندى بوده و

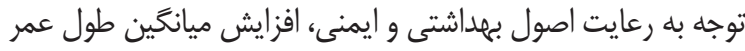

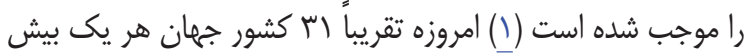

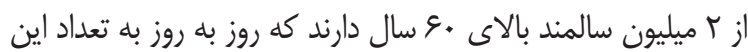

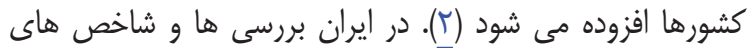
أمارى حاكى از رشد برشتاب سالمندى مى دهد، در همين راستا،

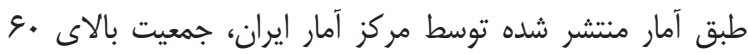

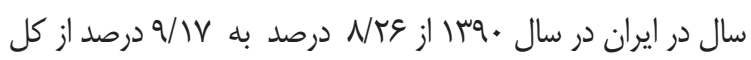
جامعه در سال هوجا رسيده است. به طورى كه ييش بينى مى شود

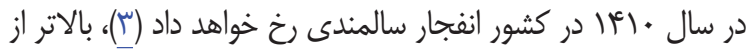
نيمى (\$ه٪) از جمعيت سالمندان جهان در حال حاضر در كشورهاى در حال توسعه زندگى مى كنند و تخمين زده شده است تا سال •r.r اين ميزان به (لى٪ برسد (أ). با ورود به مرحله سالمندى و با افزايش سن تغييرات مختلفى در عمكرد فيزيولوزيكى و ساختارى در بدن افراد خخ خواهد داد كه (ه) مهم ترين مسئله در اين ميان مربوط به حفظ استقلال در فعاليتهاى روزمره و ادامه زندَّى به صورت فعال مى باشد (و). زمين خوردن

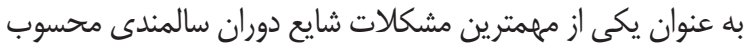
مى گَردد (Vا). زمين خوردن عواقب و عوارض جسمانى (شكستن

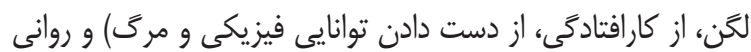
(از دست دادن اعتماد به نفس، عزت نفس و كاهش اميد به زندكى) زيادى را به همراه دارد (9،1). در اين رابطه، كوازاكى و همكاران (ץ) به نقل از نشان مى دهند در حدود •4 درصد از هزينه

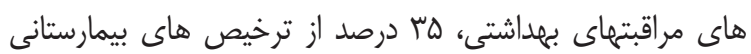
و FV درصد از روزهاى بسترى در بيمارستانها را سالمندان به خود اختصاص مى دهند (•). برخى محققين معتقدند كه كاهش تعادل بعنوان اصلى ترين عامل موثر در زمين خوردن سالمندان به شمار مى ميى رود و به همين دليل فاكتور تعادل و بازتوانى آن در اين كروه سنى مورد توجه بسيارى از محققين ديخر قرار كَفته است (I)). از نظر فيزيولوزيكى تعادل، تعامل ميان سطوح مكانيزم هاى كنترل تعادل و از نظر بيومكانيكى به عنوان توانايى حفظ و بركشت مركز ثقل بلدن در محدوده پايدارى به وسيله اتكاء، تعريف مى شود (T).). بنابراين قابليت فرد در حفظ بدن در يك حالت ايستا يا يويا را تعادل كويند. تعادل تركيبى از هماهنگى بين سيستم هاى تعادلى، شامل

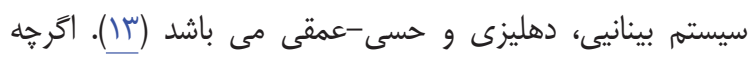
محققين بويزه فيزولوزيست ها معتقدند كه تنها انجام فعاليت هاى دئي 
مطالعه سعى شد تا از قرار گَرفتن نمونه ها در معرض تمرينات ديخر

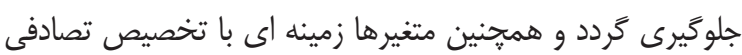
نمونه ها در بين سه كَروه و استفاده از آزمون هاى آمارى تحت كنترل

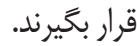
ابزارهاى مورد استفاده در اين مطالعه جهت انجام ارزيابى اوليه

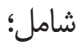
() فرم ثبت اطلاعات دموكًرافيك محقق ساخته

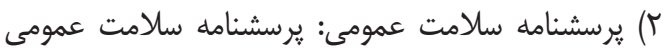

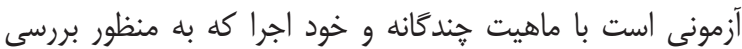
اختلالات غير روان گسسته كه در وضعيت هاى مختلف جامعه يافت مى شود طراحى شده است. يرسشنامه سلامت عمومى اولين بار

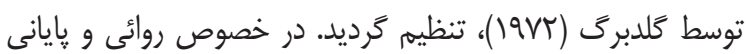
يرسشنامه سلامت عمومى در كشورهاى مختلف تاكنون مطالعات فراوانى صورت كَفته است. همجنين در تحقيق كه توسط تقوى

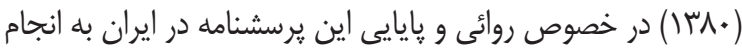
رسانده است، نشان مى دهد كه فرم ب سوالى اين يرسشنامه در داخل كشور از روائى و يايايى بالا و بسيار رضايت بخش برخوردار فران

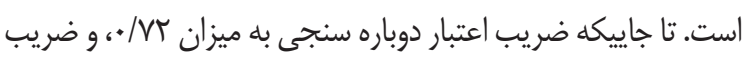
تنصيفى برابر با سو/• و ضريب آلفاى •9/.و همجنين محاسبه روائى همزمان نيز مويد روائى و بايايى بالا در برسشنامه سلامت عمومى نماني

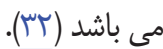
r) يرسشنامه آمادَى فعاليت بدنى: اين برسشنامه يك (ب) يرسشناهه غربالكرى بوده و در سال ra19 اميلادى توسط بنكتسون و اسجاردر طراحى گرديده است. محققين بسيارى در توسعه آن دست داشته اند و همجنين روايى و پِايايى آن توسط محققين بسيارى از جمله بيتزر و همكاران (1) (1) به اثبات رسيده است. يرسشنامه

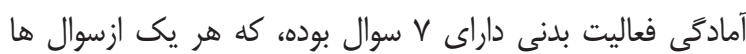

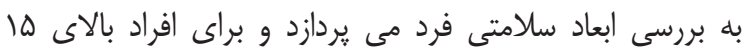
سال توصيه شده است، تا قبل از ورود به يك برنامه تمرينى حتماً يرسشنامه آمادگى فعاليت بدنى را بر نموده، و در صورت مثبت بودن إنى نتايج آن براى هر فرد (در صورتى كه ياسخ فرد به يك يا بيش

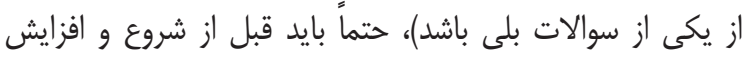

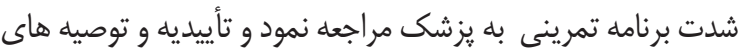
يز شكى متناسب را دريافت نمود (سب). א) يرسشنامه فرم كوتاه وضعيت ذهنى: اين يرسشنامه به عنوان ابزار مناسبى براى تشخيص و غربالكرى دمانس بكار مى رود كه اولين بار توسط تنگ و جويى (I9NV) طراحى شده و در كشور
يارامترهاى تعادل ايستا و يوياى سالمندان مرد بوده است.

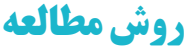

مطالعه حاضر از نوع نيمه تجربى، بوده و داراى طرح سه كروهى همراه با مداخلات تمرينى در دو كروه تجربى (ميدانى و

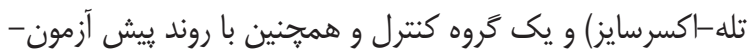

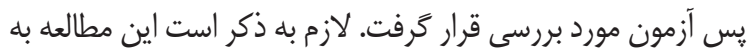
جهت تخصيص سازى تصادفى نمونه ها به دو كروه تجربى و يك كروه كنترل و با توجه به وجود مداخله تمرينى بر روى سالمندان همجنين داراى طرحى از نوع كارآزمايى غير تصادفى كنترل شده

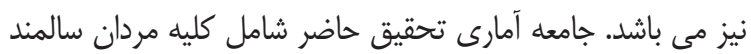

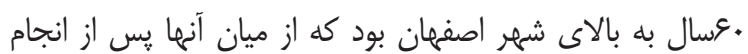
فراخوان هاى عمومى و هدفمند به منظور غربالحرى •عا نفر

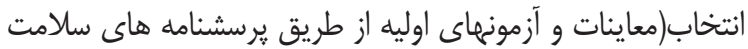
عمومى، فرم كوتاه وضعيت ذهنى و آمادَى فعاليت بدنى و انجام مصاحبه و بيان محاسن و معايب تحقيق) و در نهايت تعداد •و نفر بر فران اساس نتايج و حجم نمونه هاى مطالعات قبلى مشابه بصورت هدفمند و در دسترس انتخاب و بصورت تصادفى در سه كَروه • ب نفره تقسيم بندى شدند و در اين مطالعه حتى الامكان سعى شده تا آزمودنيها از لحاظ سن، قد، جرم بدن و همجنين شاخص توده بدنى همكن باشند. معيارهاى ورود به مطالعه مرد بالاى •9 سال، به همراه

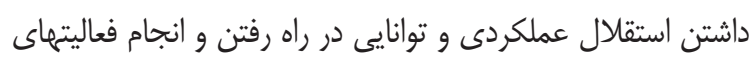
روزمره بدون استفاده از وسيله كمكى و همجنين نداشتن فعاليتهاى

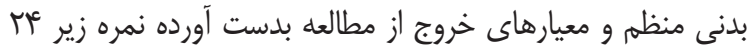
از برسشنامه فرم كوتاه وضعيت ذهنى ، نداشتن الزمات يرسشنامه

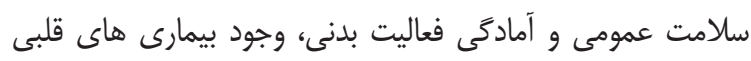

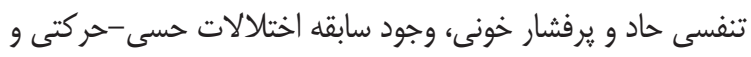
يا مشكلات شديد بينايى، وجود علائم ياتولوزيك، سابقه شكستكى، جراحى و بيمارى مفصلى در اندام تحتانى، استفاده از داروى آرام بخش و ضد درد مץ ساعت قبل از اجراى آزمون، وجود هركَونه ناهنجارى قابل مشاهده در اندام تحتانى، داشتن سابقه زمين خوردن طى يك سال كذشته، عدم توانايى در اجرايى آزمونها و يا برنامه هاى تمرينى، و مشاركت در برنامه تمرينى منظم خارج از مطالعه بود. متغير مستقل در اين مطالعه شامل فاكتور بين گروهى يا همان اجراى تمرينات ميدانى با نظارت مستقيم و تمرينات ورزشى از راه دور (تله اكسرسايز) به مدت م هفته بوده و متغير وابسته در مطالعه حاضر شامل تعادل و شاخص هاى مرتبط با آن مى باشد. در اين 
خود اقدام به انجام تمرينات مى نمودند، لازم به توضيح آنكه مربى

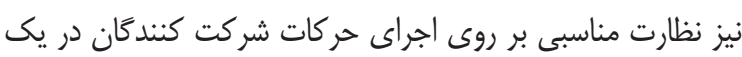
برنامه تمرينى تله اكسرسايز (از راه دور) داشته است. تمرينات ميدانى نيز با حضور مربى و شركت كنندكان در يك باشخاه رزمى سريوشيده به انجام رسيد. لازم به توضيح آنكه سعى شد جهت حفظ ايمنى و

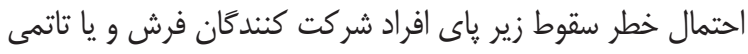

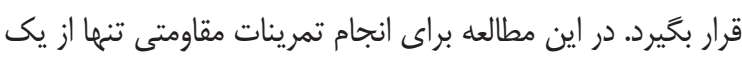

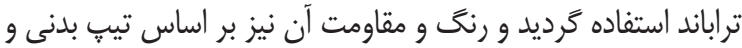
نيروى آزمودنى ها انتخاب شد. به منظور تجزيه و تحليل داده ها، از آمار توصيفى جهت مرتبط كردن داده ها و جهت تحليل داده ها از روش تحليل واريانس براى

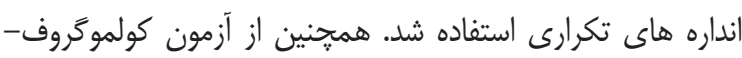

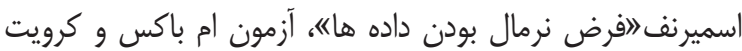
ماجلى (شرط همسانى ماتريس هاى كوواريانس و فرض همخنى واريانسها) نيز استفاده شد. تمام تجزيه و تحليل هاى مرتبط با داده

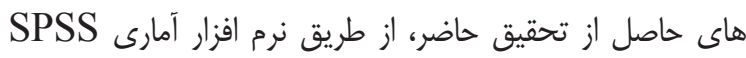
نسخه זَ به انجام رسيده است.

اين يزوهش توسط مركزتربيت بدنى دانشكاه صنعتى اصفهان، دانشكده توانبخشى دانشخاه علوم يزشكى اصفهان و دانشكده تربيت بدنى دانشكاه شهيد باهنركرمان با دريافت كد اخلاق IR.SSRI. از يزوهشكاه تربيت بدنى و علوم ورزشى به شمارهان

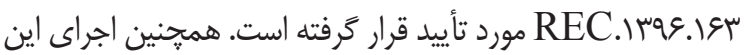
تحقيق با رعايت كامل ملاحظات اخلاقى صورت كرفت به طورى كه انجام مراحل مختلف تحقيق با بررسى سابقه يزشكى و اطمينان از سلامت آزمودنى ها و همجنين كسب رضايت نامه شركت در مطالعه براى هر كدام از آزمودنى ها همراه بود و در مورد محرمانه

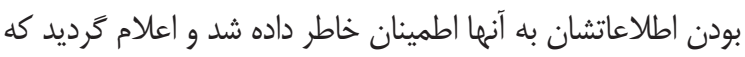
شركت در مطالعه اختيارى است، به طورى كه شركت كنندًان اجازه خروج از فرآيند يزوهش را در طول مطالعه دارند.

\section{بافْته ها}

يس از تجزيه و تحليل داده ها در بخش توصيفى و تحليل

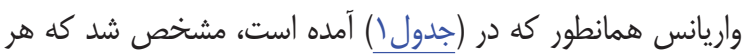
سه كَروه تجربى ميدانى و تجربى از راه دور (تله اكسرسايز) و كنترل با يكديخر از لحاظ سن، قد، جرم بدن و شاخص توده بدنى و ساير

$$
\text { شاخص ها همسان مى باشند. }
$$

ما نيز به عنوان يك ابزار مناسب در راستاى سنجش ميزان دمانس

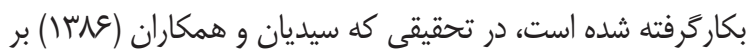
روى افر اد سالم و داراى دمانس ايرانى انجام دادند به اين نتيجه دست

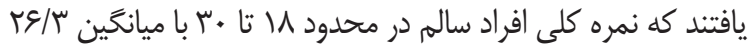

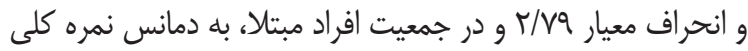

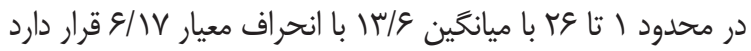
(بآ). در تحقيق حاضر نيز نمونه هايى كه داراى نمرات برابر و پاييين تر از آT بودند از تحقيق كنار كذاشته شدند. ه) جهت ثبت اطلاعات مرتبط با تعادل ايستا و يويا از آزمون

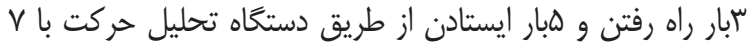
دوربين و فركانس • rا هرتز همراه با صفحه نيرو سينك شده با آن آن إنان كه در مركز تحقيقات اسكلتى عضلانى دانشكده توانبخشى دانشعاه علوم يزشكى اصفهان موجود بود انجام يذيرفت. اطلاعات موردنياز توسط مدلهاى اسكلتال حاصل از نرم افزار اوين سيم نسخه بّ,ب استخراج گَرديد. پارامتر هاى گَوناكَونى براى ارزيابى تعادل ايستاو يويا

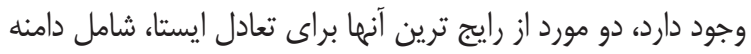
تغييرات مركز فشار در صفحه مديولترال و در صفحه آنتريويوستريور

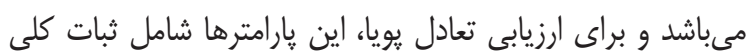
نسبت به طول يا و ثبات داخلى خارجى نسبت به عرض كام مى باشد. برنامه تمرينى كه به عنوان يك مداخله در اين مطالعه مورد

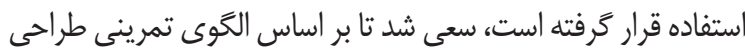
شده توسط بست-مارتينى و جونز-ديخِنووا (أ (+) براى سالمندان به سبك نهايت آمادگى (اولتيمت فيت - يك جلسه، شامل جنائ جاين بخش تمرينى بوده و هر يارت تمرينى بصورت تركيبى از جندين نوع تمرين و با شدت متفاوت بر اساس توانايى هر فرد بوده القدتى لمتى و مقاومتى، استقامت قلبى -عروقى، تعادلى و دامنه حركتى"، و لازم

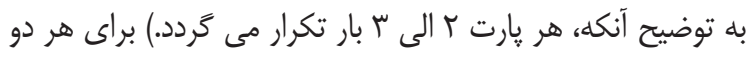

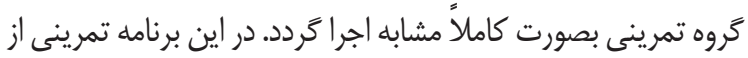

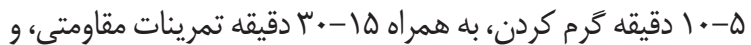

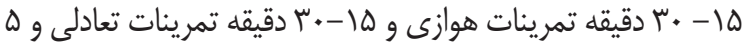
دقيقه سرد كردن استفاده شود، تمرينات در هر هفته بصورت فزآينده بر اساس توانايى نمونه ها افزايش مى يافت.

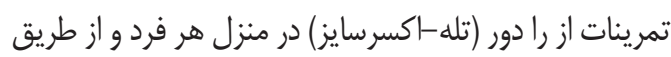
اينترنت و استفاده از نرم افزار هنگ اوتس متعلق به شركت كو كل انجام يذيرفت، بدينصورت كه مربى و شركت كنندكان با اتصال به اينترنت و استفاده از نرم افزار مربوطه با يكديخر ارتباط مجازى برقرار نموده و با مشاهده حر كات مربى بر روى صفحه رايانه و يا تلفن همراه 
جدول (: مقايسه همسانى سه كروه تجربى ميدانى، تجربى تله اكسرسايز وكنترل از نظر متغيرهاى دموكر افيكى

\begin{tabular}{|c|c|c|c|c|}
\hline سطح معنى دارى & $\begin{array}{c}\text { كروه تجربى تله اكسرسايز } \\
\text { (Mean } \pm \text { SD) }\end{array}$ & $\begin{array}{c}\text { كروه تجربى ميدانى } \\
\text { (Mean } \pm \text { SD) }\end{array}$ & $\begin{array}{c}\text { گروه كنترل } \\
(\text { Mean } \pm \text { SD) }\end{array}$ & \\
\hline 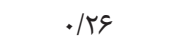 & $\varepsilon r / V r \pm r / \Lambda \varepsilon$ & $G F / T \Lambda \pm Y / F F$ & $G r / \Delta \Lambda \pm r / r r$ & سن (سال) \\
\hline.$/ N E$ & $1 / V r \pm \cdot / \cdot r$ & $\mid / Y I \pm \cdot / \cdot r$ & $1 / V T \pm \cdot / \cdot \Delta$ & قد (m) \\
\hline.$/ 94$ & 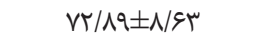 & $V \Gamma / \Delta \Lambda \pm \Lambda / r r$ & $V / \Lambda r \pm q / r \Lambda$ & جرم بدن (kg) \\
\hline.$/ 9 \Delta$ & 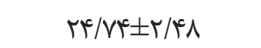 & $r E / \& V \pm r / \mathcal{E}$ & $r F / \Lambda \Delta \pm r / \Delta r$ & شاخص توده بدنى (kg/m \\
\hline שא/. & $\cdot|\Lambda \subseteq| \pm \cdot / r \Lambda$ & שא. & ./VQs $\pm \cdot / r T$ & Aاخص PAR-Q \\
\hline$\cdot / D F$ & $r I / V F \pm I / r \Delta$ & $r \cdot / 91 \pm 1 / 4 r$ & $r I / r r \pm I / r r$ & MMSE شاخص \\
\hline سو/. & $|N / 4| \pm|\cdot| r \mid$ & 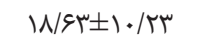 & $\left|N / \varepsilon \wedge \pm 1 \cdot /{ }^{\prime}\right|$ & شاخص GHQ \\
\hline
\end{tabular}

بررسى ييش شرط هاى مرتبط با آزمون تحليل واريانس تركيبى با

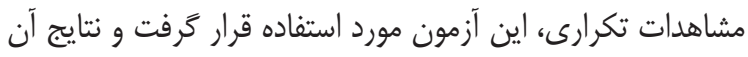
در (جدول r) آمده است.
در ابتداء ميانگين و انحراف معيار نمرات ييش آزمون و

يس آزمون در گروه هاى تجربى و كنترل براى پارامترهاى مرتبط

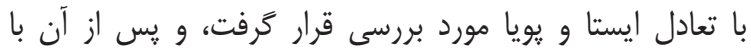

جدول r: نتايج تحليل واريانس تركيبى با مشاهدات تكرارى مربوط به اثرات درون و بين گروهى

\begin{tabular}{|c|c|c|c|c|c|c|c|c|c|}
\hline تآمارى & اندازه اثر & معنادارى سطح & $\mathrm{F}$ & مجذانگين & آزادى درجه & مجذورات & منبع تغييرات & اثرات & متغير \\
\hline \multicolumn{10}{|c|}{ تعادل ايستا } \\
\hline $\begin{array}{l}.199 \\
.191 \\
.14 \\
.199 \\
.199 \\
.119 \\
1 \\
1 \\
.199 \\
.199 \\
.119 \\
.170 \\
.199 \\
.199 \\
.149 \\
1 \\
1 \\
.199\end{array}$ & 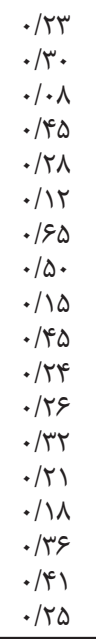 & 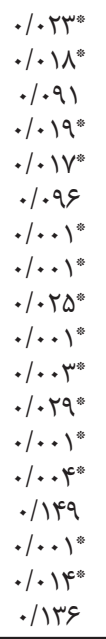 & 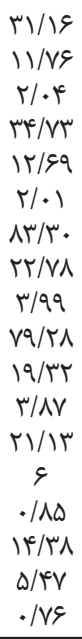 & 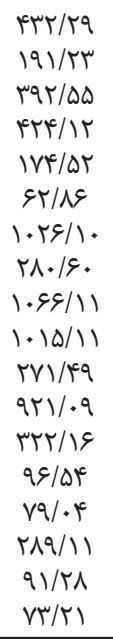 & $\begin{array}{l}y / \cdot q \\
r / 19 \\
r \\
y / \cdot r \\
r / \cdot q \\
r \\
y / \cdot r \\
r / \cdot r \\
r \\
y / \cdot r \\
r / \cdot g \\
r \\
y / \cdot r \\
r / \cdot g \\
r \\
y / 1 . \\
r / \cdot q \\
r\end{array}$ & 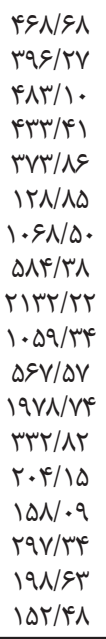 & 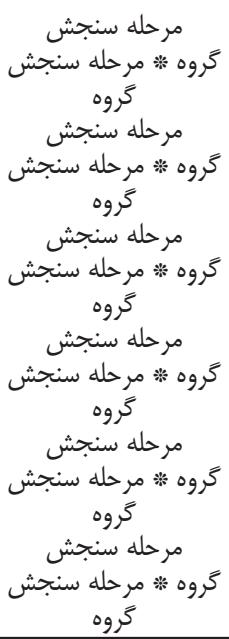 & 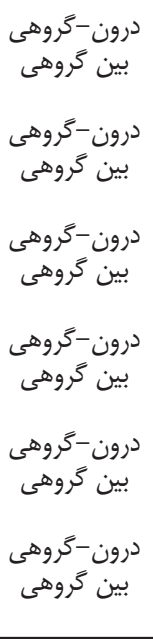 & $\begin{array}{l}\text { COP Excursion } \\
\text { AP } \\
\text { COP Excursion } \\
\text { ML } \\
\text { Path Length AP } \\
\text { Path Length ML } \\
\text { COP Velocity } \\
\text { AP }\end{array}$ \\
\hline \multicolumn{10}{|c|}{ تعادل يويا } \\
\hline $\begin{array}{c}1 \\
1 \\
.1145 \\
.198 \\
.191 \\
.114 \\
1 \\
1 \\
.194\end{array}$ & $\begin{array}{l}. / 1 V \\
. / 4 \Delta \\
. / 4 \Delta \\
. / 8 T \\
. / Q N \\
. / 4 V \\
. / 4 R \\
. / 4 Q \\
. / 4 T\end{array}$ & 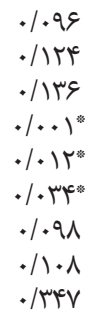 & 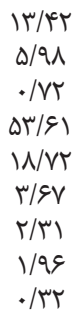 & 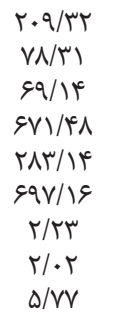 & 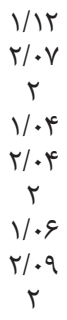 & 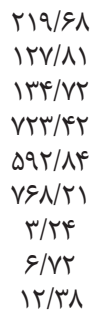 & 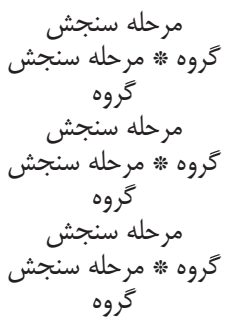 & 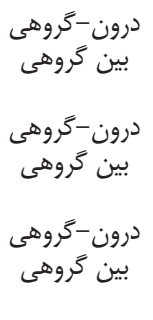 & ثبات داخلى خارجى باه عرض \\
\hline
\end{tabular}

* نشان دهنده وجود تفاوت معنادار مى باشد.

بيانخًر آن است كه گروه هاى يثوهش در زمان هاى مختلف اندازه كيرى متفاوت رفتار كرده اند. همجنين نتايج قسمت پإيين جدول در هر زير مقياس (اثرات بين گروهى) نشان مى دهد كه ميانخين

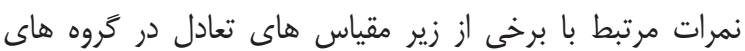
مختلف مطالعه با يكديخر تفاوت معنادار داشته و اثر گروه معنادار
برآورد مقادير مربوط به تحليل واريانس تركيبى با مشاهدات تكرارى بيانگر اين است كه اثرات درون گروهى مربوط به مرحله سنجش و تعامل گروه و مرحله سنجش و همجنين اثربين گروهى

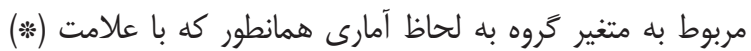
مشخص شده است معنادار است (ه • (PS) در واقع معنادارى تعامل 
نشان مى دهد كه ميانخين نمرات مرتبط با برخى زير مقياس هاى مرتبط با تعادل در گروه هاى مختلف مطالعه با يكديخر تفاوت معنادار نداشته و اثر گروه معنادار نشده است. به منظور بررسى اينكه بين كدام تروه ها و در كدام مرحله تفاوت وجود دارد نياز به مقايسه هاى زوجى (جدول س) وجود دارد.

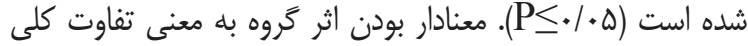
ميانكَين نمرات مرتبط با برخى از زير مقياس هاى تعادل در بين كَروه هاى مورد مطالعه (تجربى ميدانى، تجربى تله-اكسرسايز و كنترل) مى باشد. لازم به توضيح است كه برخى ديخر از زيرمقياس هاى مرتبط با تعادل در بخش پايين هر زير مقياس (اثرات بين گروهى)

جدول سا: تتايج مقايسه زوجى زيرمقياس هاى مرتبط با تعادل ايستا و يويا در مراحل مختلف و به تفكيك گروه

\begin{tabular}{|c|c|c|c|c|c|}
\hline \multicolumn{2}{|c|}{ يس آزمون } & \multicolumn{2}{|c|}{ ي پيش آزمون } & \multirow[b]{2}{*}{ كروه ها } & \multirow[b]{2}{*}{ متغير } \\
\hline معنادارى & ميانغَين & معنادارى & ميانغين & & \\
\hline \multicolumn{6}{|c|}{ تعادل ايستا } \\
\hline$\cdot / 9 M$ &.$- / 199$ & •/A & $-\cdot|\Delta|$ & ه اكسرسايز & \multirow{4}{*}{ COP Excursion AP } \\
\hline$\cdot \mid \cdot r I^{*}$ & $-Q / \Delta T$ & $\cdot \mid \& \Lambda$ & $1 / 91$ & & \\
\hline 每: & $-r / g r$ & $\cdot / \Delta \Lambda$ & $r / 4 q$ & سايز-كنترل & \\
\hline - trat & $-\cdot / \mathrm{IV}$ & $\cdot / V \Delta$ & $-\bullet / 1 \mu$ & ل مه اكسرسايز & \\
\hline.$/ . r \omega^{*}$ & $-r / f q$ & $\cdot / \Delta \Delta$ & $1 / \cdot 1$ & 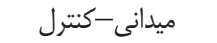 & \multirow{2}{*}{ COP Excursion ML } \\
\hline$\cdot \mid \cdot r I^{*}$ & $-r / r r$ & $\cdot / \& V$ & $1 / 41$ & سايز-كنترل & \\
\hline$\cdot / \Delta \wedge \Delta$ & N/VTF & $\cdot / \mathrm{N}^{\mathrm{N}}$ & V/AFQ & له اكسرسايز & \multirow{3}{*}{ Path Length AP } \\
\hline$\cdot / \cdot r^{*}$ & $-\omega \cdot / \mu r$ & $\cdot / 91$ & $-N / \cdot 10$ & & \\
\hline$\cdot / \cdot r^{*}$ & $-09 / \cdot 9$ & $\cdot|0|$ & $-\mid Q / \Lambda \varepsilon$ & ايز-كنترل & \\
\hline$\cdot / 4 \cdot 1$ & - & $\cdot / \Delta V$ & $\Delta / \wedge \Delta$ & لمله اكسرسايز & \multirow{3}{*}{ Path Length ML } \\
\hline$\cdot / \cdot r^{*}$ & $-s \varphi / \mu q$ & • ( I & $11 / \cdot \varphi^{4}$ & & \\
\hline.$/ . Y^{*}$ & $-\Delta \Psi / I \varepsilon$ & $\cdot / \Delta \Delta$ & $0 / 19$ & سايز-كنترل & \\
\hline ( & $-|\cdot| q \mu \mid$ & $\cdot / 4 I V$ & $-.19 \cdot 9$ & له اكسرسايز & \multirow{3}{*}{ COP Velocity AP } \\
\hline$\cdot / \cdots e^{* *}$ & $-r / \cdot r q$ & •/rNI & $-\cdot / V^{e}$ & & \\
\hline$\cdot / \cdot r^{*}$ & $-1 / 4+9$ & $\cdot / \Delta S V$ & - & سايز-كنترل & \\
\hline 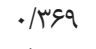 & $-\cdot / V I V$ & $\cdot / r \Delta \Lambda$ & $-\cdot / T V T$ & له اكسرسايز & \multirow{3}{*}{ COP Velocity ML } \\
\hline$\cdot / \cdot r^{*}$ & $-r / \cdot 9 V$ & ו ואו/. & - ( & إمرل & \\
\hline $.1 . \cdot 9^{*}$ & $-1 / \mu \wedge$. & $. / 4+9$ & $-\cdot 1+\mathrm{M}$ & سايز-كنترل & \\
\hline \multicolumn{6}{|c|}{ تعادل يويا } \\
\hline . IFTA & $\cdot / \mu \cdot 1$ & . & ( & له اكسرسايز & \multirow{3}{*}{ ثبات كلى نسبت به طول پا } \\
\hline . ligr & $\cdot / F \Delta V$ & 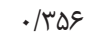 & . / & & \\
\hline$\cdot|| f \mid$ & $\cdot / D Q S$ & $\cdot / r \cdot 9$ & $-.1 \cdot 90$ & تله اكسرسايز-كنترل & \\
\hline$\cdot / D P q$ & $-\cdot / r \Lambda I$ & $\cdot|9 V|$ & $-1 / 891$ & ميدانى -تله اكسرسايز & \multirow{4}{*}{ ثبات داخلى خارجى نسبت به } \\
\hline$\cdot / \cdot r^{*}$ & $V / 194$ & | & $-1 / 1 \mu \alpha$ & ميدانى -كنترل & \\
\hline$\cdot / \cdot r^{*}$ & N/QGY & DL & •/DQH & تله اكسرسايز-كنترل & \\
\hline$\cdot / 9 \wedge \Delta$ & $\cdot 1 \cdot \cdot 1$ &.$/ 999$ & $-\cdot \cdot \cdot+1$ & ميدانى -تله اكسرسايز & \\
\hline$\cdot / V M$ & $-\cdot 1 \cdot \cdot 0$ & •/VVE & $-\cdot / \cdot r r$ & ميدانى-كنترل & \multirow{2}{*}{ عرض كام } \\
\hline$\cdot / V \& \Lambda$ & $-.1 \cdot .9$ & . $/ 994$ &.$- \cdot \cdot \cdot 1$ & تله اكسرسايز-كنترل & \\
\hline
\end{tabular}

* تشان دهنده وجود تفاوت معنادار مى باشد.

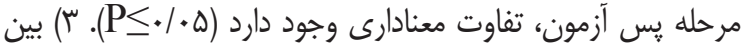
دو گروه تجربى به لحاظ ميانخين زير مقياس هاى مرتبط با تعادل در

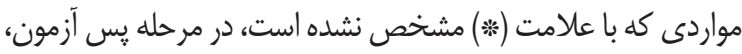
تفاوت معنادارى وجود ندارد.

در (نمودارهاى(اوب) به مقايسه سه گروه تجربى ميدانى، تجربى تله-اكسرسايز و كنترل در دو مرحله ييش آزمون و يس أزمون پرداخته شده است.
مقادير برآورده شده در (جدول؟) بيانكر اين است كه () بين دو گروه تجربى با گروه كنترل به لحاظ ميانگَين زيرمقياس هاى مرتبط با تعادل در مرحله ييش آزمون تفاوت معنادارى وجود ندارد.

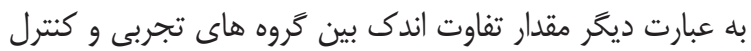
در مرحله ييش آزمون ناشى از تصادف برآورد مى شود. r) بين گروه

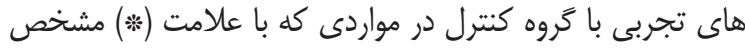
شده است، به لحاظ ميانگين زيرمقياس هاى مرتبط با تعادل در 


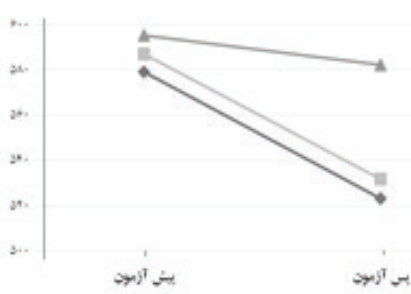

r

جمع طول مسير طى شده توسط

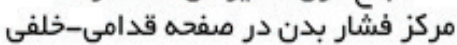

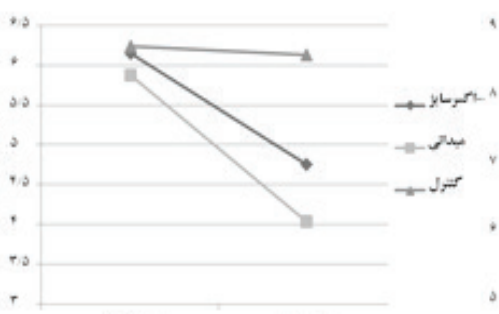

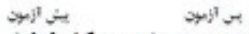

سرعت نوسان مركز فشار بدن در صفحه داخلى-خارجى مركز فرنار

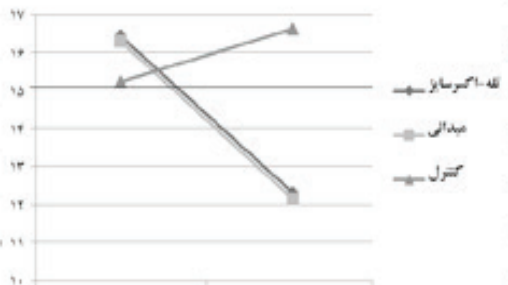

a

دامنه نوسان مركز فشار بدن

در صفحه داخلى-خارجى نونى فرنار بلى

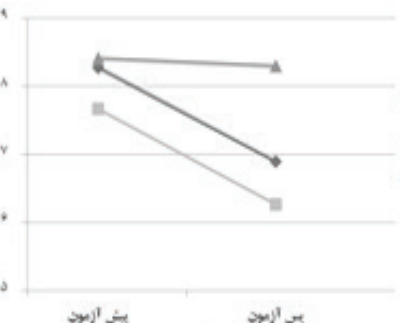

سرعت نوسان مركز فشار

بدن در صفحه قدامى-خلفى نوسن فركار

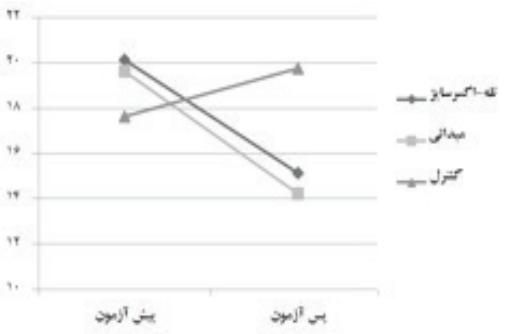

تغييرات مربوط به دامنه نوسان مركز فشار بدن در صفحه قدامى مريوطلفى
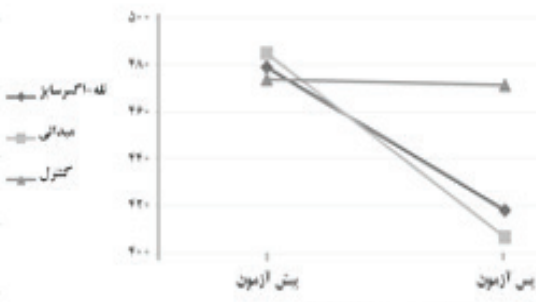

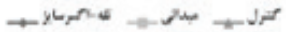

جمع طول مسير طى شده توسط مركز فشار بدن در صفحه داخلى-خارجى مشدر توسط

نمودار (ا: تغييرات يارامترهاى مرتبط با تعادل به صورت جداكانه در هر كداميك از يارامترهاى مرتبط با تعادل

نشان دهنده افزايش يارامترهاى مرتبط با تعادل ايستا در گروه تجربى تله اكسرسايز در مرحله يس آزمون مى باشد.
(نمودار () نشان دهنده ثبات نسبى يارامترهاى مرتبط با تعادل

ايستا در مراحل دو كانه در رَروه كنترل مى باشد. همجنين (نمودار إ)

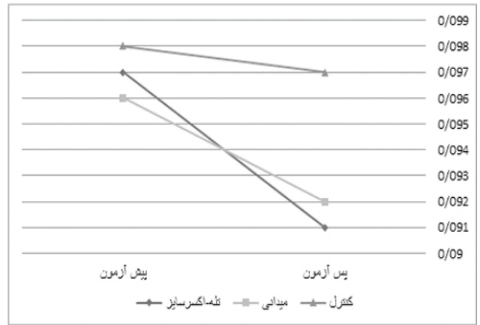

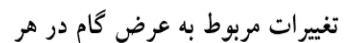

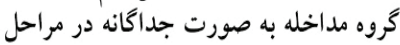
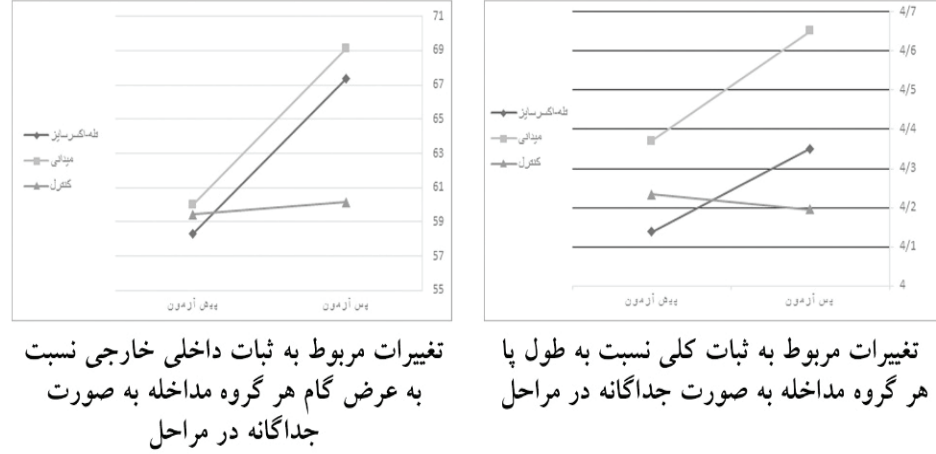

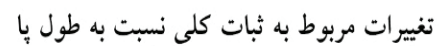

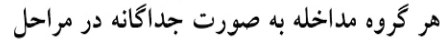

نمودار ب: تغييرات يارامترهاى مرتبط با تعادل به صورت جداكانه در هر كداميك از يارامترهاى مرتبط با تعادل يويا

آمادگى")، بر روى تعادل ايستا و يوياى سالمندان سالم مرد مورد

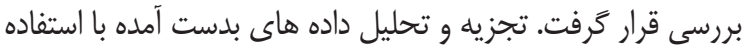
از روش آمارى تحليل واريانس براى انداره هاى تكرارى نشان داد، لتريه

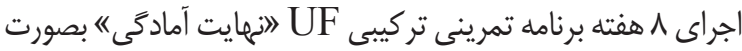
ميدانى و تله-اكسرسايز (ورزش از راه دور) بر روى يارامترهاى مرتبط با تعادل سالمندان مرد اثربخش بوده، و همجنين اثربخشى هر دو كروه تجربى با يكديخر تفاوت معنى دارى ندارد. در ادامه به تبيين دقيق نتايج حاصل از يزوهش يرداخته خواهد شد. بر اساس نتايج به دست آمده از يزوهش حاضر مشخص شد كه اجراى ^ هفته تمرين در هر دو گروه تجربى نسبت به گروه
(نمودار r) نشان دهنده ثبات نسبى يارامترهاى مرتبط با تعادل يويا در مراحل دو گَانه در گروه كنترل و همجنين ثبات نسبى در هر دو گروه تجربى در مراحل دوكانه مرتبط با پارامترهاى ثبات كلى

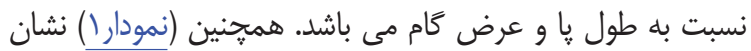
دهنده افزايش يارامتر ثبات داخلى خارجى نسبت به عرض كام در هر

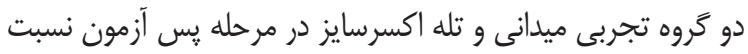
بل كنترل مى باشد.

\section{ثִ}

در اين ثيزوهش تأثير ^ هفته تمرينات تركيبى UF \انهايت 
رسيديند كه انجام تمرينات در آب و خشكى به يك ميزان باعث

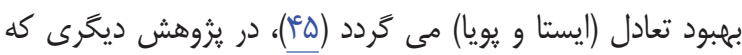
فارسى و همكاران (4و (1) بر روى اثربخشى تمرينات تعادلى، قدرتى و تركيبى (تعادل و قدرتى) بر تعادل انجام دادند به اين نتيجه دست

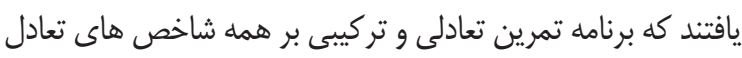

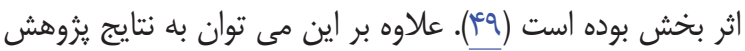

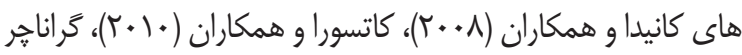

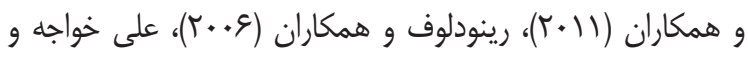

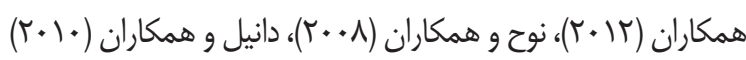

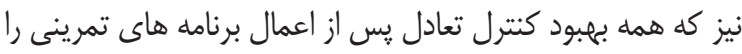

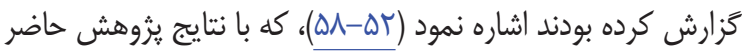

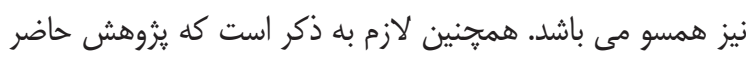

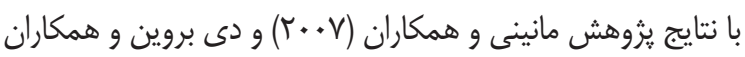

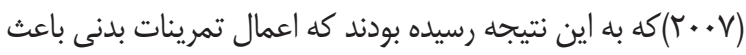

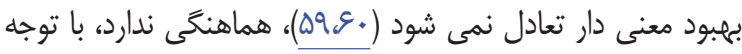

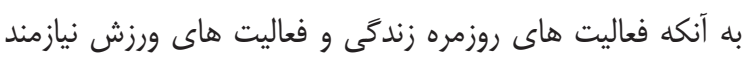

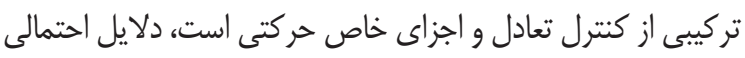

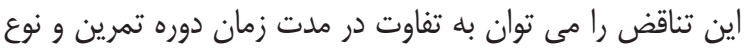

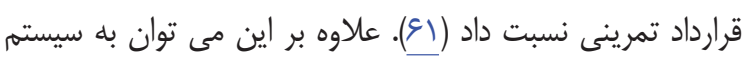

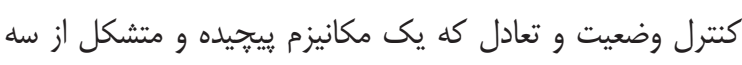
سيستم: دهليزى، حس عمقى و بصرى است اشاره نمود، همجنين بخشى از يردازش به وسيله (سيستم اعصاب مركزى) و ستون فقرات

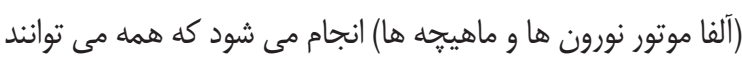

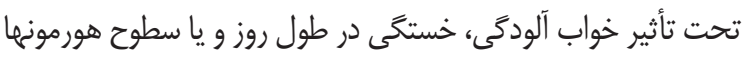
قرار گيرند (Fr). در يزوهش حاضر يارامتر ثبات كلى نسبت به طول پا كه

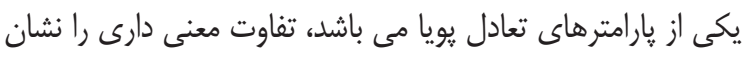

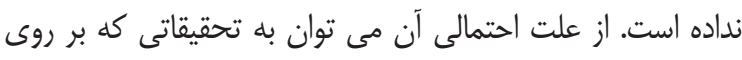

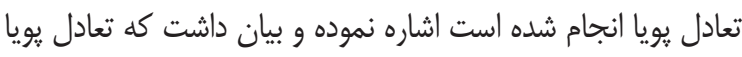

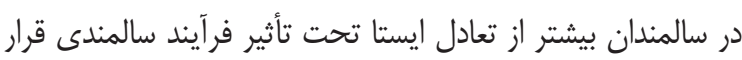

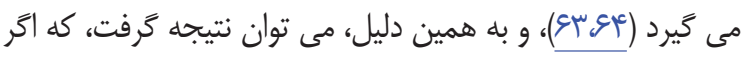

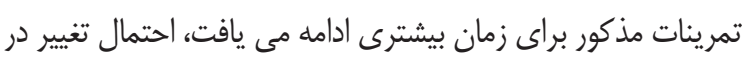
تعادل يويا بويثه ثبات كلى نسبت به طول يا إيجاد مى شع شد.

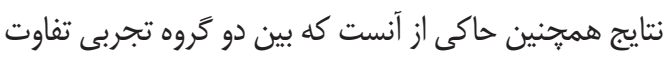

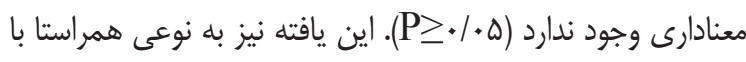

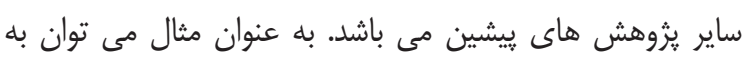

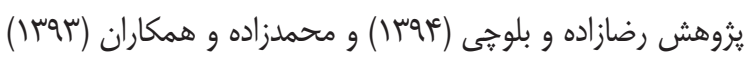
كه به بررسى دو نوع فعاليت بدنى در آب و خشكى يرداختند اشاره
كنترل مى تواند تأثير معنى دارى در بهبود تعادل ايستا و يويا داشته

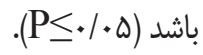
در خصوص يارامترهاى تعادل ايستا در يزوهش حاضر بايد

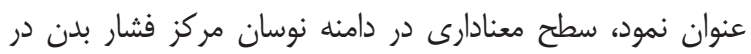
صفحه قدامى-خلفى و در صفحه داخلى-خارجى، جمع طول مسير طى شده توسط مركز فشار بدن در صفحه قدامى-خلفى و در صفحه

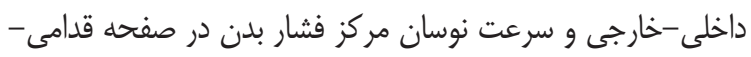
خلفى و در صفحه داخلى-خارجى تا سطح زيادى مشابه با يكديكر

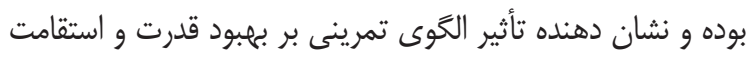

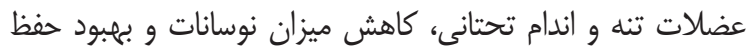
مركز ثقل در محدوده سطح اتكاء مى باشد. در خصوص يارامترهاى تعادل يويا در يزوهش حاضر باء بايد

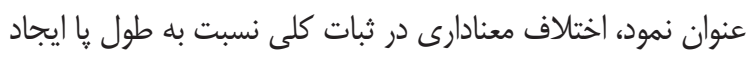

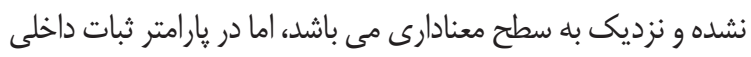

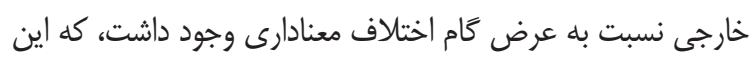

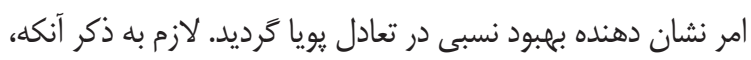
در عرض كام نيز اختاف معنادارى وجود نداشت. از دلايل عمده بهببود تعادل ايستا و يويا مى توان به مواردى إنى

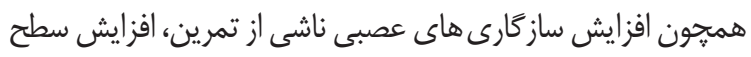

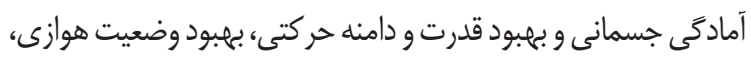
زمان واكنش و وضعيت روانى، بجبود كنترل عصبى -عضلانى شامل

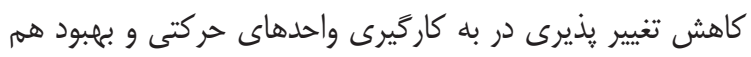
زمانى واحدهاى حركتى اشاره نمود (ـَّ).

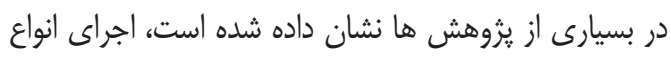
تمرينات تعادلى بصورت منظهم و مداوم طى هشت هفته مى تواند،

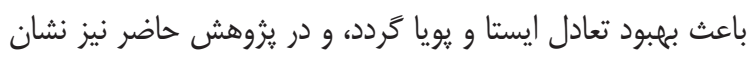

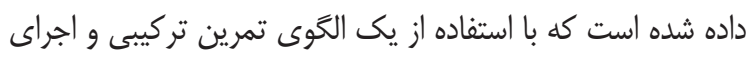

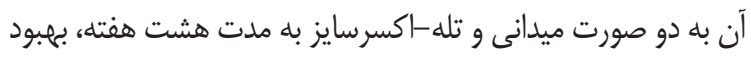

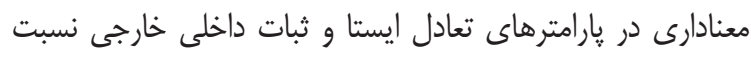
به عرض كَام به عنوان يكى از يارامترهاى تعادل يويا كَرديده و

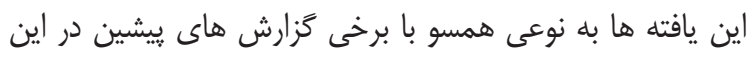

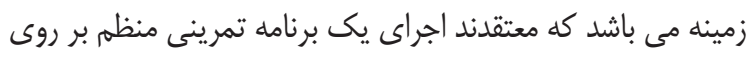
سالمندان مى تواند نقش مهمى در بهبود تعادل ايستاو يويا به همراه

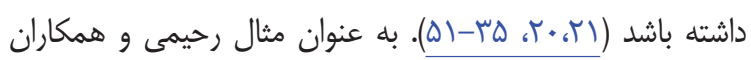

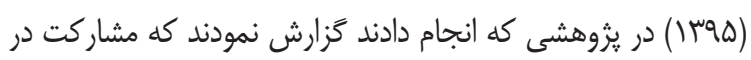

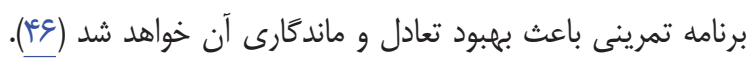

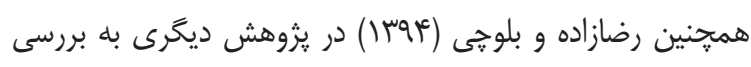

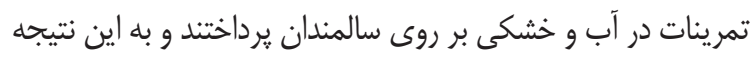


يارامترهاى مرتبط با تعادل ايستاو يويا شده و از اين رو باعث كاهش خطر افتادن در اين كروه سنى نيز كرديده است. از طرفى نتايج حاكى

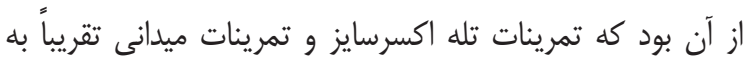
يك نسبت موجب بهبود در متغيرهاى اين يزوهش گرديده اند. بدين ترتيب و با توجه به اثربخشى تمرينات تله اكسرسايز همراستا با تمرينات ميدانى، مى توان از تمرينات تله اكسرسايز و فوايد اينكُونه تمرينات براى كروه سنى سالمندان بهره مند كرديد.

با بكاركيرى يك برنامه ورزشى و فعاليت فيزيكى منظم و مداوم به دو صورت ميدانى و تله اكسرسايز مى توان ابعاد مختلف كيفيت زندَّى بخصوص ويثَيهاى بدنى و سلامتى را در افراد افزايش داده و باعث استقلال بيشتر فرد سالمند در انجام كارهاى برى روزانه شد و به فرآيند سالمندى موفق كمى زيادترى نمود و راه را براى بهبود كيفيت زندگى در سالمندان هموار نمود تا بتوان از اين طريق از تجربيات ارزشمند سالمندان در راستاى اعتلاى جامعه

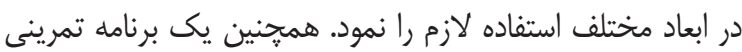
تله اكسرسايز مى تواند جايخزين مناسبى براى يك برنامه تمرينى ميدانى باشد. يشنهرادات:

• به محققين و متخصصين توصيه مى شود كه برنامه تمرينى مورد استفاده در اين يزوهش را در برنامه ريزيهاى تمرينى جهت يبيشَيرى از زمين خوردن و عدم تعادل و بهبود كيفيت راه رفتن و

$$
\text { نيروى عضلانى در سالمندان در نظر بخيرند. }
$$

• از طرفى با توجه به عدم وجود اختلاف معنى دار در دو كروها تجربى (ميدانى و تله اكسرسايز)، بنظر بتوان از تمرينات تله اكسرسايز

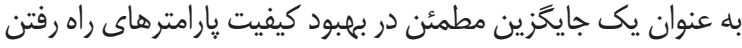
و خطر افتادن، تعادل، نيروى عضلانى و كيفيت زندگى استفاده نمود.

\section{References}

1. Bashiri G, Hadi M, Bashiri M, H R. The effect of 6 weeks of resistance training - balance, Speed - balance and balance on The dynamic balance of active older men. Journal of Sports Sciences. 2010;26:149-56.

2. Ahmadi M, Noudehi M, Esmaeili M, Sadrollahi A. Comparing the Quality of Life Between Active and Non-Active Elderly Women With an Emphasis on Physical Activity. Iranian Journal of Ageing. 2017; 12 (3): 262-75.

3. Mirmoezzi M, Amini M, Khaledan A, Khorshidi D. Effect of 8-week of selected aerobic exercise on static and dynamic balance in healthy elderly
نمود، و درانتها به اين نتيجه دست يافتند كه تفاوت معنادارى بين انجام تمرينات در آب و خشكى وجود ندارد، همجنين نتايج يزوهش

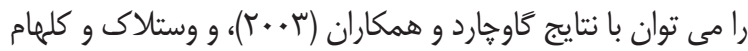
(Y) (Y.V) اين عدم تفاوت در اين دو روش را مى توان اينخكونه تبيين نمود، كه در هر دو روش تمرينى مورد استفاده يك الكَوى تمرينى ارائه كَرديد، و در هر جلسه تمرينى بصورت مجزا بر روى تعادل ايستا

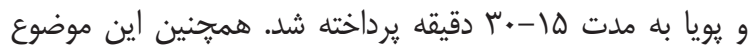
بيانكَ اين است كه اجراى صحيح، با دقت و همراه با نظارت تمرينات بصورت تله اكسر سايز مى تواند بر روى تعادل ايستاو يوياى سالمندان تأثير نسبتاً يكسانى با تمر ينات ميدانى داشته باشد. از آنجا كه تحقيقات بسيارى نشان داده اند، تمرينات تركيبى توانايى مناسبى در بهبود بارامترهاى تعادل، قدرت، استقامت و ساير بارامترهاى مرتبط با سلامتى و تندرستى دارند، در تمرينات استفاده

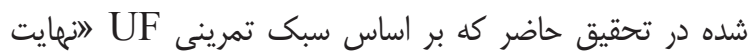

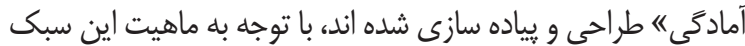
كه كاملا بصورت تركيبى بوده و خندين متغير (تمرينات تعادلى، قلبى -عروقى، قدرت و استقامت عمومى و ناحيه ثبات مركزى، انعطاف يذيرى) را با يكديخر در يك جلسه تمرينى تركيب مى في نمايد، مى توان اينكَونه عنوان نمود، با توجه به اثربخشى در بهبود بانيا

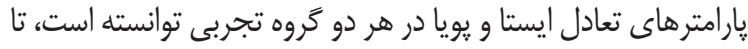
حد زيادى باعث كاهش ميزان سقوط در گَروه سنى سالمندان كَردد.

\section{تنيجه تيرى نهائى}

يزوهش حاضر نشان داد كه اجراى ^ هفته تمرينات تركيبى (تركيبى از تمرينات؛ تعادلى، استقامتى، قدرتى، هوازى، بى هوازى،

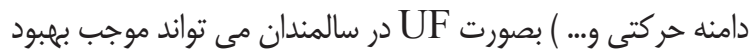
inactive men. Iranian Journal of Ageing. 2016; 11 (1): 202-9.

4. Darabi S, Torabi F. Analysis and Comparison of Aging Population in Europe and Asia During 1950 to 2015. Iranian Journal of Ageing. 2017; 12 (1): 30-43.

5. Azizi A, Sepahvandi MA, Peyda N, Mohamadi J. Effective Approach to the Study of Aging: Grounded Theory Study. Iranian Journal of Ageing. 2016;10(4):88-101.

6. Moeini B, Barati M, Jalilian F. Factors associated with the functional independence level in older adults. Hormozgan Medical Journal. 2012; 15 (4): $318-26$. 
7. Hamed Z, Ali.Asghar N, Pour Mahmoodian P, Shviklo J. Investigating the relationship between fear of falling, knee joint proprioception and physical activity level with fullerton advanced balance test in elderly in rasht city in 2016 . Journal of Gerontology. 2017; 1 (3): 68-78.

8. Lopes K, Costa D, Santos L, Castro D, Bastone A. Prevalence of fear of falling among a population of older adults and its correlation with mobility, dynamic balance, risk and history of falls. Brazilian Journal of Physical Therapy. 2009; 13 (3):223-9.

9. Sereshti M, Nahidi F, Simbar M, Ahmadi F, Bakhtiari M, Zayeri F. Mothers' Perception of Quality of Services from Health Centers after Perinatal Loss. Electronic physician. 2016;8 (2): 2006.

10. Kozaki K, Murata H, Kikuchi R, Sugiyama Y, Hasegawa H, Igata A, et al. " Activity scale for the elderly" as a measurement for the QOL of local elderly individuals and the assessment of the influence of age and exercise. Nihon Ronen Igakkai zasshi Japanese journal of geriatrics. 2008; 45 (2):188-95.

11. Clark RA, Bryant AL, Pua Y, McCrory P, Bennell K, Hunt M. Validity and reliability of the Nintendo Wii Balance Board for assessment of standing balance. Gait \& posture. 2010;31(3): 307-10.

12. Darvishi.A, MD. The competitive balance Iranian the league by League Soccer Selected European Countries. Journal of Sport Management and motor behavior. 2012; 6 (31): 427-38.

13. Hertel J. Sensorimotor deficits with ankle sprains and chronic ankle instability. Clinics in sports medicine. 2008; 27 (3): 353-70.

14. Chodzko-Zajko WJ, Proctor DN, Singh MAF, Minson CT, Nigg CR, Salem GJ, et al. Exercise and physical activity for older adults. Medicine \& science in sports \& exercise. 2009; 41 (7): 1510-30.

15. Hosseini FS, Hossein zadeh R. Effect of physical activity on physical and mental health in elderly men. Journal of Health and Care. 2011;13 (2):0.

16. Garatachea N, Molinero $\mathrm{O}$, Martínez-García R, Jiménez-Jiménez R, González-Gallego J, Márquez S. Feelings of well being in elderly people: relationship to physical activity and physical function. Archives of Gerontology and
Geriatrics. 2009; 48 (3): 306-12.

17. Eime RM, Young JA, Harvey JT, Charity MJ, Payne WR. A systematic review of the psychological and social benefits of participation in sport for children and adolescents: informing development of a conceptual model of health through sport. International journal of behavioral nutrition and physical activity. 2013;10 (1): 98.

18. Lee Y-J, Hung W-L. The relationship between exercise participation and well-being of the retired elderly. Aging \& mental health. 2011; 15 (7): 873-81.

19. Farsi A, Ashayeri H, Mohammadzadeh S. The effect of balance training on hip, knee, and ankle joints Kinematic compatibility of older women during walking. 2016.

20. Atashin Panjeh L, Bagherpour T, MohammadEbrahim B. Comparison of eight weeks of Pilates and power exercises on dynamic balance in elderly women of Dezful city. 1st International Conference on Sportd Science. 2015.

21. Sadeghi H, Norouzi H, Karimi Asl A, Montazer M. Functional Training Program Effect on Static and Dynamic Balance in Male Able-bodied Elderly. Iranian Journal of Ageing. 2008; 3 (2): 565-71.

22. zareyi h, Norasteh Aa. The effect of combined training (strenging and stretching) on balance, the risk of falling and quality of life of older people. The Scientific Journal of Rehabilitation Medicine. 2017.

23. Wu G, Keyes LM. Group tele-exercise for improving balance in elders. Telemedicine Journal \& E-Health. 2006; 12 (5): 561-70.

24. Wu G, Keyes L, Callas P, Ren X, Bookchin B. Comparison of telecommunication, community, and home-based Tai Chi exercise programs on compliance and effectiveness in elders at risk for falls. Archives of physical medicine and rehabilitation. 2010; 91 (6): 849-56.

25. Geraedts H, Zijlstra A, Bulstra SK, Stevens M, Zijlstra W. Effects of remote feedback in homebased physical activity interventions for older adults: a systematic review. Patient education and counseling. 2013; 91(1):14-24.

26. Asadi AR, Khorzoghi M, Sahebozamani M. The Effect of Three-Month Therapeutic and Ergonomic Exercise Based on Virtual Space on Musculoskeletal Disorder in Computer Users. 
British Journal of Applied Science \& Technology. 2015; 9 (3): 256-67.

27. Babaei Khorzoghi M, Nadi MA, Rahnama N, Sajjadian P. Comparative effect of exercise therapy and ergonomics methods based on a virtual space on computer users with neck pain. Journal of Research and Health. 2017; 7 (3):86976.

28. BABAEI M, RAHNAMA N, NADI MA, SAJADIAN $P$. The effect of exercise therapy and ergonomic based on virtual space in computer users with low back pain. 2013.

29. Babaei Khorzoghi M, Sajjadian P. A Study on Musculoskeletal Disorders in Computer Game Users Compared with Other Users. IJCRB. 2013; 7 (4): 258-69.

30. Babaei Khorzoghi M, Sahebozamani M, MohammadTaghi K, Amir MR. EVALUATING THE EFFECTIVENESS OF TWO TYPES OF EXERCISES, FIELD EXERCISE WITH DIRECT SUPERVISION (FEWDS) AND REMOTELY EXERCISE (TELE-EXERCISE) ON THE QUALITY OF LIFE OF THE ELDERLY MAN. 2018.

31. Khorzoghi MB, Sahebozamani M, Seyfaddini MRA, Karimi MT. The Effectiveness of Remote Exercise (tele-exercise) on Static Equilibrium Parameters of the Elderly Man. 2018.

32. Malakouti SK, Fatollahi P, Mirabzadeh A, Zandi T. Reliability, validity and factor structure of the GHQ-28 used among elderly Iranians. International Psychogeriatrics. 2007; 19 (4):62334.

33. Pitzer L, Fingerman KL, Lefkowitz ES. Development of the parent adult relationship questionnaire (PARQ). The International Journal of Aging and Human Development. 2011; 72 (2):111-35.

34. Foroughan M, JAFARI Z, SHIRIN BP, GHAEM MFZ, RAHGOZAR M. Validation of minimental state examination (MMSE) in the elderly population of Tehran. 2008.

35. Cromwell RL, Meyers PM, Meyers PE, Newton RA. Tae Kwon Do: an effective exercise for improving balance and walking ability in older adults. The Journals of Gerontology Series A: Biological Sciences and Medical Sciences. 2007; 62 (6):641-6.

36. Karimzadeh Shirazi K, Sh N, Heydarnia A.
Effects of a TTM-based osteoporosis preventive physical activity education, on increasing muscle. Hakim Research Journal. 2007; 10 (2): 34-42.

37. Sadeghi H, Hemati Nezhad MA, Baghban M. The effect of endurance training on a few kinematics parameters ingait of non-active elderly people. Iranian Journal of Ageing. 2009; 4 (1).

38. Shamsipour-Dehkordy P, Aslankhani M, Shams A. Effects of physical, mental and mixed practices on the static and dynamic balance of aged people. Journal of Shahrekord University of Medical Sciences. 2011; 12 (4): 71-7.

39. Bahgeri H, Abdolvahab M, Raji P, Jalili M, Faghih Zadeh S, Soltani Z. The effects of progressive resistive exercises on Activities of Daily Living of elderly persons. Journal of Modern Rehabilitation. 2010; 4 (1):56-9.

40. Hanachi P, Kaviani G. Impact of mini trampoline exercise on dynamic balance in old women. Bimonthly Journal of Hormozgan University of Medical Sciences. 2010; 14 (2):148-55.

41. HOSSEINI MSS, ROSTAMKHANY H, NAGHILOO Z, LOTFIN. The effects of balance, mental and concurrent training on balance in healthy older males. 2010.

42. Abdoli B, Shams A, Shamsipour Dehkordi P. The effect of practice type on static and dynamic balance in elderly $60-75$ year old women with no history of falling. Daneshvar. 2012; 19 (97):4350.

43. Rahnama N, FroughiFar R, Amini H. The effect of balance training in the morning and afternoon on static and dynamic balance in elderly. Journal of sport management and action behavior. 2015; 11(21):15-24.

44. Khoramian M, Golmohammadi B, Akbari H. The effect of the selective balanced on ball and core resistance training program on the older females. Journal of Motor Behavior. 2015;19 (7):105-22.

45. Rezazadeh N, Baluchi R. The Effect of 12 Weeks Exercise in the Water and Land on the Static and Dynamic Balance and the Risk of Falling the Old People. Iranian Journal of Ageing. 2016;10 (4):140-51.

46. Rahimi M, rajabi r, Alizadeh M, Piri H. The investigation of effect and durability of selected aerobic trainings on dynamic balance in healthy elderly females. Journal of research in sport 
rehabilitation. 2016; 7 (4): 65-72.

47. Bashiri J, Hadi H, Bashiri M, Rostamkhany H. Comparison effect of six week resistancebalance, velocity-balance and balance training on dynamic balance in active elderly males. J Rehabil Sci. 2009; 5 (2):104-15.

48. Balochi R. The effect of balance training on postural factors in the elderly. Journal of Applied Sport Physiology (JASP). 2015; 11 (21):93-102.

49. Farsi A, Abdoli B, Baraz P. Effect of balance, strength, and combined training on the balance of the elderly women. Iranian Journal of Ageing. 2015; 10 (3):54-61.

50. Soori R, Akbarnejad A, NaseriMobarake E, DokhtAbdiyan r, Zeinali V. The Effect of Water Exercises on Physiological Indices and BioMotor Capabilities of Sedentary Elderly Men. Journal of sport biosciences. 2015; 7 (1):57-76.

51. AKBARNEJAD A, KONESHLOU S, BARANCHI M. The Effect of 12 Weeks of Functional Training and Different Periods of Detraining on Dynamic Balance in Elderly Men. 2015.

52. Kaneda K, Sato D, Wakabayashi H, Hanai A, Nomura T. A comparison of the effects of different water exercise programs on balance ability in elderly people. Journal of Aging and Physical Activity. 2008; 16 (4): 381-92.

53. Katsura Y, Yoshikawa T, Ueda S-Y, Usui T, Sotobayashi D, Nakao H, et al. Effects of aquatic exercise training using water-resistance equipment in elderly. European journal of applied physiology. 2010; 108 (5): 957-64.

54. Granacher U, Muehlbaue T, Zahner L, Gollhofer A, Kressig RW. Comparison of traditional and recent approaches in the promotion of balance and strength in older adults. Sports medicine. 2011; 41(5):377-400.

55. Alikhajeh Y, Hosseini SRA, Moghaddam A. Effects of hydrotherapy in static and dynamic balance among elderly men. Procedia-Social and Behavioral Sciences. 2012; 46: 2220-4.

56. Daniel F, Vale R, Giani T, Bacellar S, Dantas E. Effects of a physical activity program on static balance and functional autonomy in elderly women. Macedonian Journal of Medical Sciences. 2010; 3 (1): 21-6.

57. Lindelöf N. Effects and experiences of highintensity functional exercise programmes among older people with physical or cognitive impairment: Luleå tekniska universitet; 2008.

58. Noh DK, Lim J-Y, Shin H-I, Paik N-J. The effect of aquatic therapy on postural balance and muscle strength in stroke survivorsa randomized controlled pilot trial. Clinical rehabilitation. 2008; 22 (10-11): 966-76.

59. Manini T, Marko M, VanArnam T, Cook S, Fernhall B, Burke J, et al. Efficacy of resistance and task-specific exercise in older adults who modify tasks of everyday life. The Journals of Gerontology Series A: Biological Sciences and Medical Sciences. 2007;62 (6): 616-23.

60. de Bruin ED, Murer K. Effect of additional functional exercises on balance in elderly people. Clinical rehabilitation. 2007; 21 (2): 112-21.

61. Brill P. Functional fitness for older adults.[SR. Attarzadeh Hosseini, E. Davoudi Sharifabad, Persian trans]. Mashhad: Beh Nashr Publication. 2008:85.

62. Jorgensen M, Rathleff MS, Laessoe U, Caserotti P, Nielsen O, Aagaard P. Time-of-day influences postural balance in older adults. Gait \& posture. 2012; 35 (4): 653-7.

63. Kuptniratsaikul V, Praditsuwan R, Assantachai P, Ploypetch T, Udompunturak S, Pooliam J. Effectiveness of simple balancing training program in elderly patients with history of frequent falls. Clinical interventions in aging. 2011;6:111.

64. Fouroghi R, Farzan-Moghadam F, Rahnama N. Comparing the effects of time of day on balance performance in elderly. Physiology of Exercise and Physical Activity. 2013; 5 (1): 725-34.

65. Westlake KP, Culham EG. Sensory-specific balance training in older adults: effect on proprioceptive reintegration and cognitive demands. Physical therapy. 2007; 87 (10):127483. 